\title{
The Effect Of Cryotherapy On Various Blood Gases Parameters For Athletes
}

\author{
By \\ Yasser A. Nour Eldin \\ Department of Sport Health Science - Faculty of Physical Education for Men \\ - Helwan University - Egypt
}

\section{Abstract}

The aim of the research is to study the effect of cryotherapy method on blood gases (PCO2,PO2,HCO3 and $\mathrm{PH}$ ) and its influence on the recovery of athletes after running 10 $\mathrm{Km}$. The researcher used the experimental method by using (pre-post- 60 mins post measurements) on an experimental group and a passive group because it suits the nature of the research. The sample was composed of 7 runners in each group with an average age of 20.5 chosen by the intentional method. Each group had to run $10 \mathrm{~km}$. The experimental group had their bodies covered with ice packs for 20 minutes while the second group had a passive rest for 60 minutes. The athletes approved that blood samples would be withdrawn in all measurements of the research before, immediately after and after 60 minutes. The results showed there are statistical difference for the cryotherapy group in all measured parameters( $\mathrm{PCO} 2, \mathrm{PO} 2, \mathrm{HCO} 3$ and $\mathrm{PH})$ in favor of the first post measurement. It was evident from the results that when cryotherpy was applied, the measured parameters returned to the pre-measured values. This highlights the positive effect of cryotherapy on the recovery process of athletes. The researcher recommends further studies to be done on the influence of cryotherapy on anaerobic exercises as well as changing the 60 mins post measurement to shorter timings.

\section{Key words : cryotherapy, blood gases (PCO2,PO2,HCO3),PH}

\section{Introduction}

Zagrobelny et al. 1999; Jezierski 2006 stated that the term "cryotherapy" was first used in 1908 by A.W. Pusey to describe the treatment of skin lesions with very low temperatures. Currently, cryotherapy refers to various treatments aimed at lowering the body surface temperature without tissue destruction.

The first very low temperature cold rooms, a peculiar form of cryostimulation appeared in Japan in 1981,when Yamauchi successfully used a cryogenic chamber to treat rheumatism (Yamauchi 1989). Whole-body cryotherapy (WBC), as it is known today, consists of acute exposure to very cold air in special cryochambers. The air is maintained at temperatures ranging from -110 to $-160^{\circ} \mathrm{C}$, limiting exposure to
3-4 minutes (Zagrobelny 2003). One of the most well-established physiological responses to cold exposure is triggered by the decrease in skin temperature, promptly stimulating cutaneous receptors and their sensory afferents to excite sympathetic adrenergic fibers, in turn causing the constriction of local arterioles and venules The resulting decrease in blood flow to the periphery or injured/inflamed tissues, reduces local metabolic processes, thereby attenuating the inflammatory response and the formation of oedema around the injured tissues (Paddon-Jones DJ ; Quigley BM 1997).It has been shown that cryotherapy reduces cell necrosis and neutrophil migration and slows cell metabolism and nerve conduction velocity, 
which in turn reduce secondary tissue damage and pain sensation (Wilcock et.al 1999). The body's response to low temperature depends on the temperature, method of application, exposure time, method and rate of heat loss, humidity of the cooled air, and the characteristics and age of the subjects.In the sporting realm, WBC (in this instance, more accurately defined as whole-body cryostimulation) has been used at temperatures ranging from $-110{ }^{\circ} \mathrm{C}$ to $-160{ }^{\circ} \mathrm{C}$ with the aim of limiting the spread of muscle lesions after training or competing ( Swenson ; sward ;Klimek 1996).

It has also been offered as a prophylactic treatment to reduce the risk of muscle lesions during intense training periods and to increase the antioxidant status after multiple exposures (Lubkowska et.al 2008). Despite the increasing popularity of WBC in sports, only few studies have assessed its efficiency in accelerating the recovery of the athlete (Rymaszewska et.al 2008 ; Banfi et.al 2010 ; Hausswirth et.al 2011) .Very recently, post-exercise cold water immersion has been shown to aid recovery by altering blood flow (Vaile et.al 2011) and improving perceptions of recovery(Stanley J; Buchheit M; Peake JM 2012) which may be reflected by changes in cardiac autonomic activity (Buchheit $\mathrm{M}$ 2009) .WBC may also exert important effects on post-exercise recovery at the cardiovascular level. As exercise causes an intensity-dependent parasympathetic withdrawal and sympathetic increase, a prompt recovery of parasympathetic activity is desirable after exercise. Changes in cardiac parasympathetic activity as assessed by heart rate variability (HRV) analysis have emerged in the literature as a global recovery index that reflects the acute response of the body to exercise; an elevated level of parasympathetic activity allowing rapid cardio deceleration and faster recovery (Stanley J; Buchheit M; Peake JM -2012, Al Haddad H -2010, Stanley J ; Buchheit M; Peake JM -2013)
Wilcock et al. 2006 mentioned that athletes adopt a variety of strategies to help them recover between training sessions and competitive events to maintain performance. Water immersion is a popular method to improve recovery, as evidenced by its widespread use during the recent London Olympic Games.

Poppendieck et al. 2013 stated that despite the widespread use of cold water for recovery, its effect on exercise performance is variable. Stanley et al. 2013; Vaile et al. 2008 agreed that although cold water immersion may benefit subsequent sprint and endurance exercise performance, it can also impair subsequent sprint performance (Parouty et al. 2010) or not alter endurance performance (Stanley et al. 2012).

Banfi et al. 2010 stated that cryostimulation is used in athletic recovery, acceleration of recovery to full physical ability, and removing the results of muscle fiber damage caused by intense exercise. It is promoted as a treatment method for muscle injuries, syndromes of overuse and to enhance recovery between training sessions

Costello (2011)performed studies to evaluate the immediate effect of cryostimulation on proprioception and tried to evaluate the effectiveness of this treatment in muscle soreness and function following eccentric exercise damage. Based on obtained results, the authors suggest that although cryostimulation does not increase the risk of proprioceptive related injury, it is ineffective in improving recovery if administered $24 \mathrm{~h}$ after exercise. Pournot et al. 2011 compared the effect of two different recovery modalities: cryostimulation $\left(3 \mathrm{~min}\right.$ at $\left.-110^{\circ} \mathrm{C}\right)$ and passive recovery, on markers of exerciseinduced muscle damage and inflammation obtained after a simulated trail running race. The recovery session was applied immediately after, $24 \mathrm{~h}, 48 \mathrm{~h}$ and $72 \mathrm{~h}$ after subjects performed a 48min running treadmill exercise. The authors observed that a unique session of 
cryostimulation performed immediately after exercise enhanced muscular recovery by restricting the inflammatory process. They suggested that soluble receptor antagonist IL-1ra increases after single whole-body cryostimulation and restricts the inflammatory response to exercise by a decrease in the magnitude if $\mathrm{IL}-1$ and protein C-reactive. This physiotherapeutic treatment reduces the time of recovery, although depending on the time lag from the intense effort to cryostimulation. Further studies are required for a detailed understanding of mechanisms of response to cryogenic temperatures to find their most effective application in athletic training and recovery

Literature on changes in haematological indices induced by cryostimulation are often inconsistent and insufficient. Blatteis (1998) reported a decrease in leukocytes and erythrocytes in healthy subjects after a series of cryostimulations. Stanek et al. 2006, reported that there was no significant increase in leukocytes, although a significantly increased percentage of monocytes in healthy individuals after a series of 10 two-minute long cryostimulations at $-120^{\circ} \mathrm{C}$ was observed. Lubkowska et al. 2009 stated an increase in the number of lymphocytes and monocytes, and to a lesser extent, neutrophils and eosinophiles. With regards to information on the effect of cryotherapy or cryostimulation on the red blood cell system, data is still very scarce. The only available paper is Banfi et al. 2008 which investigated the effects of 5 sessions of whole-body cryotherapy treatment on haematological values in athletes. The paper suggested that cryotherapy does not have detrimental effects on the mentioned parameters, but a small significant decrease in haemoglobin concentration, mean corpuscular haemoglobin and mean reticulocyte volume were observed

In terms of the participation of white and red blood cells in effort ability and tolerance, further studies are required on potential changes in haematological indices in response to varied number of cryostimulation in a series. Cold exposure is a risk factor for hypertension. Blood pressure is measured, before cryostimulation, but contraindications to the use of cryotherapy do not include unstable blood pressure or hypertension. Literature data on changes in key cardiovascular indicators in humans exposed to cryogenic temperatures are ambiguous.Westerlund et al. 2004 ; Fricke 1989; Taghawinejad et al. 1989 reported a significant but short-term increase in systolic and diastolic blood pressure after WBC in both normotensive and mildly hypertensive individuals. Zalewski 2009 reported that thermal stress $\left(-110^{\circ} \mathrm{C}\right)$ did not cause changes in systolic or diastolic blood pressure but only a decrease in the heart rate.

The effect of WBC on the concentration of different hormones have been studied. Soccer players undertaking ten sessions of cryostimulation followed by 60 minutes of kinesitherapy, had a significant decrease in the concentration of testosterone and estradiol. Reports of changes in the level of cortisol (defined as the stress hormone) are divergent. Smolander et al. 2009 concluded that WBC treatments $\left(-110^{\circ} \mathrm{C}\right)$, for $2 \mathrm{~min}$, three times a week for 12 weeks, do not lead to disorders related to secretions of the growth hormone, prolactin, thyrotropin or thyroid hormones in healthy females.

Lubkowska et al. 2008 explained that one session of whole-body cryostimulation causes changes in the prooxidantantioxidant balance. The level of total oxidative status in plasma was statistically significantly decreased at 30 minutes after leaving the cryochamber and remained lower the following day, whereas the level of total antioxidative status decreased after cold exposure and increased the next day.

Woźniak et al. 2007 additionally, a $36 \%$ increase was observed in the activity of superoxide dismutase (SOD), 
glutathione peroxidase (GPx) and conjugated dienes (CD) in healthy individuals after a single stimulation. Moreover those authors concluded that prolonged, regular cryostimulation or winter swimming for 12 weeks did not appear to be harmful regarding antioxidative capacity. Further studies are needed for the confirmation of potential adaptational advantages occurring in antioxidative response to cryostimulation.

Cryotherapy is used in the early treatment of acute injuries (sprains, strains, fractures) but only a few papers discuss any possible influence of whole-body cryostimulation on inflammation mechanisms or immunology. Lubkowska et al 2010 reported an increase in the level of white blood cells in response to a series of 10 cryostimulations, and at the same time showed that a single 3 minute long whole-body cryostimulation $\left(-130^{\circ} \mathrm{C}\right)$ leads to an increase in the level of interleukin 6 , which is maintained for the next 10 stimulations. This was later confirmed which additionally showed the more advantageous effect of 20 sessions compared to 10 or 5 cryostimulations. This advantageous effect - an increased level of anti-inflammatory cytokines (IL-6, IL-10, IL-12) - was maintained during the whole series of cryostimulations, and receded no earlier than after two weeks after the completion of the cryostimulations, regardless of the number of treatments. Lubkowska et al. 2008 observed the decreased level of pro-inflammatory IL-1 during the series of 5 and 10 treatment, in an examination two weeks after the last stimulation ,the IL-1 decrease was maintained only after the series of 20 cryostimulation treatments.
Ihsan et al. 2013 mentioned that to date, only one study has examined the effect of post-exercise cold water immersion on muscle oxygenation and blood flow. However, no research has examined the effects of cold water immersion on both central (i.e., cardiac output) and peripheral (i.e., muscle oxygenation) facilitators of $\mathrm{O} 2$ delivery to exercising muscle, or its effects on the anaerobic contribution during subsequent exercise. Understanding these effects is fundamental to optimize cold water immersion as a strategy to recover from exercise. The aim of this study is to investigate the effects of cold water immersion on blood gases $\mathrm{O} 2$, $\mathrm{PCO} 2, \mathrm{HCO} 3$ as well as the blood PH on 2 groups. Cryotherapy was applied to the first group using ice packs while other group used passive therapy after running $10 \mathrm{Km}$. The research hypothesis that there are positive effects following the use of cryotherapy.

\section{Method}

\section{Participants}

The sample was composed of 14 athletes with an average age of 20.5 chosen by the intentional method. They were divided into 2 groups, experimental group and passive group. Each group had 7 athletes and homogeneity was performed among them. The criteria for choosing the participants were the players had the personal will and motive to participate in the research and the complete knowledge of the steps of the research. Also they approved that blood samples will be withdrawn in all measurements of the research before, immediately after and after 60 minutes. Finally the physical and medical state of the players were confirmed and not to get injured during the research procedures

\section{The following table No. 1 highlights the anthropometric parameters of the research sample.}


Table 1

Differences Between Experimental and Control Group in pre-test for Physical Variables in Group

\begin{tabular}{|c|c|c|c|c|c|c|}
\hline Variable & Group & Mean & $\begin{array}{l}\text { Mean } \\
\text { Rank }\end{array}$ & $\begin{array}{l}\text { Sum of } \\
\text { Ranks }\end{array}$ & $\begin{array}{c}\text { Mann- } \\
\text { Whitne } \\
\text { y U }\end{array}$ & sig \\
\hline \multirow{2}{*}{ Training years } & experimental & 5.000 & 7.500 & 52.500 & \multirow{2}{*}{24.500} & \multirow{2}{*}{1.000} \\
\hline & control & 5.000 & 7.500 & 52.500 & & \\
\hline \multirow{2}{*}{ Weight } & experimental & 66.429 & 6.500 & 45.500 & \multirow{2}{*}{17.500} & \multirow{2}{*}{0.361} \\
\hline & control & 67.143 & 8.500 & $\mathbf{5 9 . 5 0 0}$ & & \\
\hline \multirow{2}{*}{ Height } & experimental & $\mathbf{1 7 4 . 8 5 7}$ & 6.857 & 48.000 & \multirow{2}{*}{20.000} & \multirow{2}{*}{0.557} \\
\hline & control & 175.143 & 8.143 & 57.000 & & \\
\hline \multirow{2}{*}{ Age } & experimental & 20.429 & 7.500 & 52.500 & \multirow{2}{*}{24.500} & \multirow{2}{*}{1.000} \\
\hline & control & 20.429 & 7.500 & 52.500 & & \\
\hline \multirow{2}{*}{ pO2 } & experimental & 79.486 & 7.000 & 49.000 & \multirow{2}{*}{21.000} & \multirow{2}{*}{0.653} \\
\hline & control & 79.543 & 8.000 & 56.000 & & \\
\hline \multirow{2}{*}{ pCO2 } & experimental & 45.629 & 7.071 & 49.500 & \multirow{2}{*}{21.500} & \multirow{2}{*}{0.701} \\
\hline & control & 46.943 & 7.929 & $\mathbf{5 5 . 5 0 0}$ & & \\
\hline \multirow{2}{*}{$\mathrm{HCO3}$} & experimental & 25.143 & 6.643 & 46.500 & \multirow{2}{*}{18.500} & \multirow{2}{*}{0.442} \\
\hline & control & 26.286 & 8.357 & $\mathbf{5 8 . 5 0 0}$ & & \\
\hline \multirow{2}{*}{$\mathbf{p H}$} & experimental & 7.394 & 7.714 & 54.000 & \multirow{2}{*}{23.000} & \multirow{2}{*}{0.847} \\
\hline & control & 7.394 & 7.286 & 51.000 & & \\
\hline
\end{tabular}

Table 1. Indicates there are no significant differences between experimental and control groups at the pre-test stage in the variables.

\section{Measures}

The researcher used the following measures:

- a-Track used to conduct the research for both groups.

- b-Stop watches for timing the performance and resting time.

- c-Centrifuging device to separate blood components.

- d-Test tubes for collecting the blood samples and preserving them without coagulating by adding heparin so completing the separation process.

- e-Ice packs and cooling tank.

\section{Procedures}

Cryotherapy recovery group

The research for the experimental group was conducted on Monday $15^{\text {th }}$ September 2015 at 8 o'clock at the track of Shams Sporting Club.
Warm up exercises were performed including light jogging and stretching exercises for 25 minutes so getting the muscles, joints and ligaments ready for the physical activity.

The group did the pre-measurement of the blood gases through a blood sample withdrawn.

The group performed an aerobic activity running $10 \mathrm{Km}$.

The group did the post-measurement of the blood gases through a blood sample withdrawn.

Cryotherapy was applied to the group. Ice packs were applied on the whole body of each athlete in a lying position for 20 minutes.

The group did the 60 minutes postmeasurement of the blood gases through a blood sample withdrawn.

\section{Passive recovery group}

The research for the passive group was conducted on Monday $15^{\text {th }}$ September 
2015 at 8 o'clock at the track of Shams Sporting Club.

Warm up exercises were performed including light jogging and stretching exercises for 25 minutes so getting the muscles, joints and ligaments ready for the physical activity.

The group did the pre-measurement of the blood gases through a blood sample withdrawn.

\section{Results}

The group performed an aerobic activity running $10 \mathrm{Km}$.

The group did the post-measurement of the blood gases through a blood sample withdrawn.

The group had a passive rest of 60 minutes.

The group did the 60 minutes postmeasurement of the blood gases through a blood sample withdrawn

The following table $\mathbf{2}$ compares the differences between the physical variables of the experimental group.

Table 2

Differences between pre-test and post-test1 and post-test2 for Physical Variables in Experimental Group

\begin{tabular}{|c|c|c|c|c|c|c|c|}
\hline Variable & Differences between & Mean & Ranks & $\begin{array}{l}\text { Mean } \\
\text { Rank } \\
\end{array}$ & Sum of Ranks & $\mathbf{z}$ & Sig \\
\hline \multirow{6}{*}{ pO2 } & \multirow{2}{*}{$\begin{array}{c}\text { pre-test and } \\
\text { post-test1 }\end{array}$} & 79.486 & Negative & 1.00 & 1.00 & \multirow{2}{*}{2.201} & \multirow{2}{*}{$* 0.028$} \\
\hline & & 89.671 & Positive & 4.50 & 27.00 & & \\
\hline & \multirow{2}{*}{$\begin{array}{c}\text { pre-test and } \\
\text { post-test } 2\end{array}$} & 79.486 & Negative & 1.50 & 3.00 & \multirow{2}{*}{0.847} & \multirow{2}{*}{0.630} \\
\hline & & 87.243 & Positive & 5.00 & 25.00 & & \\
\hline & \multirow{2}{*}{$\begin{array}{c}\text { post-test1 and } \\
\text { post-test } 2\end{array}$} & 89.671 & Negative & 5.38 & 21.50 & \multirow{2}{*}{2.384} & \multirow{2}{*}{0.203} \\
\hline & & 87.243 & Positive & 2.17 & 6.50 & & \\
\hline \multirow{6}{*}{ pCO2 } & \multirow{2}{*}{$\begin{array}{c}\text { pre-test and } \\
\text { post-test1 }\end{array}$} & 45.629 & Negative & 1.00 & 1.00 & \multirow{2}{*}{2.201} & \multirow{2}{*}{ *0.028 } \\
\hline & & 51.129 & Positive & 4.50 & 27.00 & & \\
\hline & \multirow{2}{*}{$\begin{array}{c}\text { pre-test and } \\
\text { post-test } 2\end{array}$} & 45.629 & Negative & 4.75 & 19.00 & \multirow{2}{*}{0.847} & \multirow{2}{*}{0.397} \\
\hline & & 44.114 & Positive & 3.00 & 9.00 & & \\
\hline & \multirow{2}{*}{$\begin{array}{c}\text { post-test1 and } \\
\text { post-test } 2\end{array}$} & 51.129 & Negative & 4.00 & 28.00 & \multirow{2}{*}{2.384} & \multirow{2}{*}{$* 0.017$} \\
\hline & & 44.114 & Positive & 0.00 & $\mathbf{0 . 0 0}$ & & \\
\hline \multirow{6}{*}{$\mathrm{HCO3}$} & \multirow{2}{*}{$\begin{array}{c}\text { pre-test and } \\
\text { post-test1 } \\
\end{array}$} & 25.143 & Negative & 0.00 & 0.00 & \multirow{2}{*}{2.201} & \multirow{2}{*}{$* 0.018$} \\
\hline & & 32.786 & Positive & 4.00 & 28.00 & & \\
\hline & \multirow{2}{*}{$\begin{array}{c}\text { pre-test and } \\
\text { post-test } 2\end{array}$} & 25.143 & Negative & 4.00 & 24.00 & \multirow{2}{*}{0.847} & \multirow{2}{*}{0.090} \\
\hline & & 24.043 & Positive & 4.00 & 4.00 & & \\
\hline & \multirow{2}{*}{$\begin{array}{c}\text { post-test1 and } \\
\text { post-test } 2\end{array}$} & 32.786 & Negative & 4.00 & 28.00 & \multirow{2}{*}{2.384} & \multirow{2}{*}{$* 0.018$} \\
\hline & & 24.043 & Positive & 0.00 & 0.00 & & \\
\hline \multirow{6}{*}{ pH } & \multirow{2}{*}{$\begin{array}{c}\text { pre-test and } \\
\text { post-test1 }\end{array}$} & 7.394 & Negative & 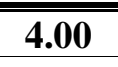 & 28.00 & \multirow{2}{*}{2.201} & $* 0018$ \\
\hline & & 7.326 & Positive & 0.00 & 0.00 & & 0.018 \\
\hline & pre-test and & 7.394 & Negative & 4.20 & 21.00 & 0847 & 0236 \\
\hline & post-test 2 & 7.378 & Positive & 3.50 & 7.00 & 0.847 & 0.250 \\
\hline & post-test 1 and & 7.326 & Negative & 0.00 & 0.00 & 2384 & $* 0018$ \\
\hline & post-test 2 & 7.378 & Positive & 4.00 & 28.00 & & \\
\hline
\end{tabular}

Tow-Related-Samples Tests - Wilcoxon Signed Ranks Test 
Table 2 indicates that there is a significant difference between (pre-test, post-test) of physical variables in experimental group for the benefit of post-test.

The following table 3 compares the differences between the physical variables of the control group.

Table 3

Differences Between pre-test and post-test1 and post-test2 for Physical Variables in Control Group

\begin{tabular}{|c|c|c|c|c|c|c|c|}
\hline Variable & Differences between & Mean & Ranks & $\begin{array}{l}\text { Mean } \\
\text { Rank }\end{array}$ & Sum of Ranks & $\mathbf{Z}$ & Sig \\
\hline \multirow{6}{*}{ pO2 } & \multirow{2}{*}{$\begin{array}{c}\text { pre-test and } \\
\text { post-test1 }\end{array}$} & 79.543 & Negative & 1.00 & 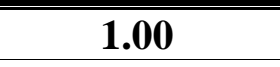 & \multirow{2}{*}{1.859} & \multirow{2}{*}{$* 0.028$} \\
\hline & & 87.929 & Positive & 4.50 & 27.00 & & \\
\hline & \multirow{2}{*}{$\begin{array}{c}\text { pre-test and } \\
\text { post-test } 2\end{array}$} & 79.543 & Negative & 1.00 & 1.00 & \multirow{2}{*}{2.023} & \multirow{2}{*}{$* 0.028$} \\
\hline & & 85.914 & Positive & 4.50 & 27.00 & & \\
\hline & \multirow{2}{*}{$\begin{array}{c}\text { post-test1 and } \\
\text { post-test } 2\end{array}$} & 87.929 & Negative & 5.50 & 22.00 & \multirow{2}{*}{0.943} & \multirow{2}{*}{0.176} \\
\hline & & 85.914 & Positive & 2.00 & 6.00 & & \\
\hline \multirow{6}{*}{ pCO2 } & \multirow{2}{*}{$\begin{array}{c}\text { pre-test and } \\
\text { post-test1 }\end{array}$} & $4 \mathbf{4 6 . 9 4 3}$ & Negative & 3.00 & 3.00 & \multirow{2}{*}{1.859} & \multirow{2}{*}{0.063} \\
\hline & & 52.029 & Positive & 4.17 & 25.00 & & \\
\hline & \multirow{2}{*}{$\begin{array}{c}\text { pre-test and } \\
\text { post-test } 2\end{array}$} & 46.943 & Negative & 0.00 & 0.00 & \multirow{2}{*}{2.023} & \multirow{2}{*}{ *0.043 } \\
\hline & & 50.800 & Positive & 3.00 & 15.00 & & \\
\hline & \multirow{2}{*}{$\begin{array}{c}\text { post-test } 1 \text { and } \\
\text { post-test } 2\end{array}$} & 52.029 & Negative & 3.75 & 15.00 & \multirow{2}{*}{0.943} & \multirow{2}{*}{0.345} \\
\hline & & 50.800 & Positive & 3.00 & 6.00 & & \\
\hline \multirow{6}{*}{$\mathrm{HCO3}$} & \multirow{2}{*}{$\begin{array}{c}\text { pre-test and } \\
\text { post-test } 1\end{array}$} & 26.286 & Negative & 0.00 & 0.00 & \multirow{2}{*}{1.859} & \multirow{2}{*}{ *0.018 } \\
\hline & & 32.300 & Positive & 4.00 & 28.00 & & \\
\hline & \multirow{2}{*}{$\begin{array}{c}\text { pre-test and } \\
\text { post-test } 2\end{array}$} & 26.286 & Negative & 1.00 & 1.00 & \multirow{2}{*}{2.023} & \multirow{2}{*}{ *0.028 } \\
\hline & & 32.071 & Positive & 4.50 & 27.00 & & \\
\hline & \multirow{2}{*}{$\begin{array}{c}\text { post-test } 1 \text { and } \\
\text { post-test } 2 \\
\end{array}$} & 32.300 & Negative & 3.75 & 15.00 & \multirow{2}{*}{0.943} & \multirow{2}{*}{0.866} \\
\hline & & 32.071 & Positive & 4.33 & 13.00 & & \\
\hline \multirow{6}{*}{ pH } & \multirow{2}{*}{$\begin{array}{c}\text { pre-test and } \\
\text { post-test } 1\end{array}$} & 7.394 & Negative & 4.50 & 27.00 & \multirow{2}{*}{1.859} & *0.028 \\
\hline & & 7.327 & Positive & 1.00 & 1.00 & & \\
\hline & pre-test and & 7.394 & Negative & 4.00 & 28.00 & 2.023 & *0.018 \\
\hline & post-test 2 & 7.343 & Positive & $\mathbf{0 . 0 0}$ & 0.00 & & \\
\hline & post-test1 and & 7.327 & Negative & 3.17 & 9.50 & 0.943 & 0.446 \\
\hline & post-test2 & 7.343 & Positive & 4.63 & 18.50 & & \\
\hline
\end{tabular}

Tow-Related-Samples Tests - Wilcoxon Signed Ranks TestTable 3 indicates that there is a significant difference between (pre-test, post-test) of physical variables (pO2 ، $\mathrm{HCO} 3$ ، $\mathrm{pH}$ ) in experimental group for the benefit of post-test. 


\section{Discussion}

It is evident from table 2 that there are statistical significances for all the research measurements (PH,HCO3,PCO2,PO2) of the experimental group for the post test 1 group meanwhile it is clear that there is no statistical significance for any of the tested variables between the pre and post 2 measurements. The decrease in post test 2 measurments after 60 minutes back to the pre test values is due to the effect of cryotherapy .This shows the effectiveness of cryotherapy on causing positive effects. Cryotherapy was reported effective in returning subjects to participation.Two potential mechanisms may be better pain control or reduced secondary tissue injury

The analgesic effect of cryotherapy is one of the primary reasons clinicians use it in the management of acute musculoskeletal injuries. Slowing of nerve conduction velocity is the likely mechanism for the analgesic response to cold. Ice reduces nerve conduction velocity and slows the stretch reflex. The greatest effect of reduced nerve conduction velocity is shown in superficial nerves $(16$ Stanley et.al 2013) and the effect of cold on nerve conduction velocity may last up to 30 minutes after application. When pain is effectively managed, the patient may be able to begin and progress rehabilitation sooner to address range-of-motion and strength deficits as well as progress to full weight bearing and functional activities more rapidly Retarding secondary injury is an important theoretic benefit of cryotherapy. Secondary tissue death has been attributed to secondary enzymatic injury and secondary hypoxic injury . Larsen et.al 2010 proposed that secondary hypoxic injury is a significant problem after injury. Cryotherapy reduces tissue temperature, slowing the rate of chemical reactions and, therefore, the demand for adenosine triphosphate (ATP) decreased the cellular ATP demand which decreases the demand for oxygen, which leads to longer tissue survival during hypoxia (Hopkins et.al 2009) By decreasing the amount of damaged and necrotic tissue, the healing process can be shortened

It is evident from table 2 that there are statistical significances for $\mathrm{PH}, \mathrm{HCO} 3$ and $\mathrm{PCO} 2$ of the experimental group between the post test 1 and post test 2.There is a decrease in the post test 2 measurements due the effect of cryotherapy. On the other hand the PO2 values decreased from 89.67 to 87.24 which is not statistically significant.

Hughson 1990 and Endo et al. 2003 stated that cardiac parasympathetic reactivation was enhanced following cold water immersion compared with passive recovery .The autonomic nervous system can influence $\mathrm{O} 2$ transport by modulating cardiovascular activity. Endo et al. 2003 reported that increased cardiac parasympathetic activity at exercise onset can reduce vagal withdrawal during the on-transient, slowing HR kinetics during high-intensity exercise. In turn, these responses may reduce peak $\mathrm{HR}$ and possibly cardiac output during sprint exercise which is also confirmed by Parouty et al. 2010.

DeLorey et al. 2007suggested that cold water immersion reduced muscle $\mathrm{O} 2$ utilization, possibly through two mechanisms. First, muscle O2 utilization may have decreased to match the reduced $\mathrm{O} 2$ delivery due to reduced muscle blood flow. Second, if cold water immersion reduced muscle temperature, then muscle $\mathrm{O} 2$ unloading may have decreased. Ferretti et al. 1995 stated that this happened in response to a temperature-dependent leftward shift in the O2-dissociation curve and also Koga et al. 2013; Shiojiri et al. 1997 stated that this happened due to slowing of muscle intracellular $\mathrm{VO} 2$ on kinetics . Dorado et al. 2004 mentioned that an $\mathrm{O} 2$ deficit is incurred at the onset 
of constant load exercise due to slower readjustment of $\mathrm{O} 2$ consumption with respect to mechanical power.

It is evident from table 2 that there is no statistical significance for the experimental group $\mathrm{PH}$ measurements between the pre test and post test 2. The blood PH data showed no significant difference between the CWI and control recovery conditions. Therefore further recovery studies should further examine PH changes within the muscle and blood. Suggested mechanisms include reduction of oedema. If muscle damage has occurred, possible increase in intracellular (Vaile J, 2008) and decrease in nerve transmission speed resulting in decreased pain perception (Stanley J, Peake JM, Buchheit M 2013). It is observed from table 2 that the measurements of the post test 2 showed positive results after cryotherapy for the experimental group. These results match with the previous studies done. It is likely that exposure to cold water caused peripheral vasoconstriction and a decrease in blood flow to the prime mover muscles. This decrease in muscle blood flow and temperature has been suggested to cause an inflammatory effect to aid muscle recovery (Yanagisawa et.al 2003). However, when the athlete must compete again within a short time of using CWI, this decrease in muscle blood flow and temperature could be detrimental to performance, even when another warm up is performed. Decreased muscle temperature and decreased core and muscle temperature have been shown to significantly decrease muscle strength and power and exercise heart rate (Howard et.al 1994).This indicates that athletes need to allow sufficient time for muscle rewarming if CWI is employed between events 


\section{Reference}

1. Al Haddad H, Laursen PB, Ahmaidi S, Buchheit M (2010) Influence of cold water face immersion on post-exercise parasympathetic reactivation. Eur J Appl Physiol 108: 599-606. doi:10.1007/ s00421-009-1253-9. PubMed: 19882167.

2. Banfi, G.; Krajewska, M.; Melegati, G. \& Patacchini, M. (2008). Effects of wholebody cryotherapy on haematological values in athletes. British Journal of Sports Medicine, No. 42, pp. 558-559

3. Banfi G, Lombardi G, Colombini A, Melegati G (2010) Whole-body cryotherapy in athletes. Sports Med 40: 509-517. doi: 10.2165/11531940-. PubMed: 20524715.

4. Blatteis, C.M. (1998). Physiology and pathophysiology of temperature regulation. World Scientific Co. Pte. Ltd. ISBN 981-02-3172-5

5. Buchheit M, Peiffer JJ, Abbiss CR, Laursen PB (2009). Effect of cold water immersion on postexercise parasympathetic reactivation. Am J Physiol Heart Circ Physiol 296: H421-H427. PubMed: 19074671.

6. Costello (2011). Different amount of sessions in healthy men. Scandinavian Journal of Clinical \& Laboratory Investigation, Vol. 71, No. 5, pp. 419-425.

7. DeLorey DS, Kowalchuk JM, Heenan AP, duManoir GR, Paterson DH (2007) Prior exercise speeds pulmonary $\mathrm{O} 2$ uptake kinetics by increases in both local muscle $\mathrm{O} 2$ availability and $\mathrm{O} 2$ utilization. J Appl Physiol 103:771-778

8. Dorado C, Sanchis-Moysi J, Calbet J (2004) Effects of recovery mode on performance, $\mathrm{O} 2$ uptake, and $\mathrm{O} 2$ deficit during high-intensity intermittent exercise. Can J Appl Physiol 29:227-244

9. Endo M, Tauchi S, Hayashi N, Koga S, Rossiter HB, Fukuba Y (2003) Facial cooling-induced bradycardia does not slow pulmonary VO2 kinetics at the onset of high-intensity exercise. J Appl Physiol 95:1623-1631

10. Ferretti G, Binzoni T, Hulo N, Kayser B, Thomet J-M, Cerretelli P (1995) Kinetics of oxygen consumption during maximal exercise at different muscle temperatures. Respir Physiol 102:261-268

11. Fricke R. (1989). Ganzkoperkaltetherapie in einer Kaltekammer mit Temperaturen $-110^{\circ} \mathrm{C}$. Z Phys Med Baln Med Klim No. 18, pp. 1-10

12. Hausswirth C, Louis J, Bieuzen F, Pournot H, Fournier J et al. (2011) Effects of whole-body cryotherapy vs. far-infrared vs. passive modalities on recovery from exercise-induced muscle damage in highly-trained runners. PLOS ONE 6: e27749. doi:10.1371/ journal.pone.0027749. PubMed: 22163272.

13. Hopkins WG, Marshall SW, Batterham AM, Hanin J (2009) Progressive statistics for studies in sports medicine and exercise science. Med Sci Sports Exerc 41: 3-13. doi:10.1249/01. PubMed: 19092709

14. Howard RL, Kramer WJ, Stanley DC, Armstrong LE March CM. The effects of cold immersion on muscle strength strength Cond Res8:129-133

15. Hughson RL (1990) Exploring cardiorespiratory control mechanisms through gas-exchange dynamics. Med Sci Sports Exerc 22:72-79 
16. Ihsan M,Watson G, Lipski M,Abbiss C (2013) Influence of postexercise cooling on muscle oxygenation and blood volume changes. Med Sci Sports Exerc $45: 876-882$

17. Jezierski, C. (2006). Methodology and principles of local cryostimulation techniques. Acta Bio - Optica et Informatica Medica, Vol. 3, No.12, pp.200 201

18. Koga S, Wu“st RCI, Walsh B, Kindig CA, Rossiter HB, Hogan MC (2013) Increasing temperature speeds intracellular PO2 kinetics during contractions in single Xenopus skeletal muscle fibers. Am J Physiol Regul Integr Comp Physiol 304:R59-R66

19. Larsen PD, Tzeng YC, Sin PY, Galletly DC (2010) Respiratory sinus arrhythmia in conscious humans during spontaneous respiration. Respir Physiol Neurobiol 174: 111-118. doi:10.1016/j.resp. 2010.04.021. PubMed: 20420940

20. Lubkowska A, Chudecka M, Klimek A, Szygula Z, Fraczek B (2008) Acute effect of a single whole-body cryostimulation on prooxidant-antioxidant balance in blood of healthy young men. J Therm Biol 33: 464-467. doi:10.1016/j.jtherbio.2008.08.003

21. Lubkowska, A.; Szyguła, Z.; Klimek, A. \& Torii, M. (2009). Do sessions of cryostimulation have influence on white blood cells count, level of IL6 and the total oxidative and antioxidative status in healthy men. European Journal of Applied Physiology, Vol. 109, No. 1, pp.67-72

22. Lubkowska, A.; Banfi, G.; Dołęgowska, B.; d'Eril, G.M.; Łuczak, J. \& Barassi, A. (2010). Changes in lipid profile in response to three different protocols of whole-body cryostimulation treatments. Cryobiology, No. 61, pp. 22-26, ISSN 0011-2240

23. Lubkowska, A.; Szyguła, Z.; Chlubek, D. \& Banfi, G. (2011). Serum mediators of inflammation level: IL-1 , IL-1 , IL-6, IL-10, IL-12 and TNF during prolonged whole-body cryostimulation treatment with different amount of sessions in healthy men. Scandinavian Journal of Clinical \& Laboratory Investigation, Vol. 71, No.5, pp. 419-25

24. Paddon-Jones DJ, Quigley BM (1997) Effect of cryotherapy on muscle soreness and strength following eccentric exercise. Int J Sports Med 18: 588593.doi:10.1055/s -2007-972686. PubMed: 9443590.

25. Parouty J, Al Haddad H, Quod M, Lepre^tre PM, Ahmaidi S, Buchheit M (2010) Effect of cold water immersion on 100-m sprint perfor-mance in well-trained swimmers. Eur J Appl Physiol 109:483-490

26. Poppendieck W, Faude O, Wegmann M, Meyer T (2013) Cooling and performance recovery of trained athletes: a meta-analytical review. Int J Sport Physiol Perform 8:227-242

27. Pournot, H.; Bieuzen, F.; Louis, J.; Fillard, J.R.; Barbiche, E. \& Hausswirth, C. (2011). Time-Course of Changes in Inflammatory Response after Whole-Body Cryotherapy Multi Exposures following Severe Exercise. PLoS ONE, Vol.6, No. 7,e22748. Doi:10.1371/journal.pone.0022748 
28. Rymaszewska J, Ramsey D, Chładzińska-Kiejna S (2008) Whole-body cryotherapy as adjunct treatment of depressive and anxiety disorders. Arch Immunol Ther Exp (Warsz) 56: 63-68. doi:10.1007/ s00005-008-0006-5. PubMed: 18250970

29. Shiojiri T, Shibasaki M, Aoki K, Kondo N, Koga S (1997) Effects of reduced muscle temperature on the oxygen uptake kinetics at the start of exercise. Acta Physiol Scand 159:327-333

30. Smolander, J.; Leppäluoto, J.; Westerlund, T.; Oksa, J.; Dugue, B.; Mikkelsson, M. \& Ruokonen, A. (2009). Effects of repeated whole-body cold exposures on serum concentrations of growth hormone, thyrotropin, prolactin amd thyroid hormones in healthy women. Cryobiology, Vol. 58, No. 3, pp. 275-278

31. Stanek, A.; Cieslar, G.; Rosmus-Kuczia, I, Matyszkiewicz, B.; Romuk, E.; Skrzep-Poloczek, B.; Birkner, E. \& Sieroń A. (2006). Influence of whole body cryotherapy on blood morphology parameters in patients with ankylosing spondylitis and in healthy volunteers. Acta Bio - Optica et Informatica Medica, Vol. 12, No. 3, pp. 207-210

32. Stanley J, Peake JM, Buchheit M (2013) Consecutive days of cold water immersion: effects on cycling performance and heart rate variability. Eur J Appl Physiol 113: 371-384. doi:10.1007/ s00421-012-2445

33. Stanley J, Buchheit M, Peake JM (2012) The effect of post-exercise hydrotherapy on subsequent exercise performance and heart rate variability. Eur J Appl Physiol 112: 951-961. doi:10.1007/ s00421-011-2052-7. PubMed: 21710292.

34. Swenson C, Swärd L, Karlsson J (1996) Cryotherapy in sports medicine. Scand J Med Sci Sports 6: 193-200. PubMed: 8896090

35. Taghawinejad, M.; Birwe, G.; Fricke, R. \& Hartman, R. (1989). Ganzkoperkaltetherapie Beeinflussung von Kreislauf - un Stoffwechselparametern. Z Phys Med Baln Med Klim, No. 18, pp. 23-30

36. Vaile J, Halson S, Gill N, Dawson B (2008) Effect of hydrotherapy on recovery from fatigue. Int J Sports Med 29:539-544

37. Vaile J, O'Hagan C, Stefanovic B, Walker M, Gill N et al. (2011) Effect of cold water immersion on repeated cycling performance and limb blood flow. Br J Sports Med 45: 825-829. doi:10.1136/bjsm. 2009.067272. PubMed: 20233843.

38. Westerlund, T.; Smolander, J.; Uusitalo-Koskinen, A. \& Mikkelsson, M. (2004). The blood pressure responses to an acute and long-term whole-body cryotherapy $\left(-110^{\circ} \mathrm{C}\right)$ in men and women. Journal of Thermal Biology Vol. 29, No 6, pp. 285-290, ISSN: 0306-4565

39. Wilcock IM, Cronin JB, Hing WA (2006a) Water immersion: does it enhance recovery from exercise? Int J Sports Physiol Perform 1: 195-206. PubMed: 19116434.

40. Wilcock IM, Cronin JB, Hing WA (2006b) Physiological response to water immersion: a method for sport recovery? Sports Med 36:747-765 
41. Woźniak, A.; Woźniak, B; Drewa, G.; Mila-Kierzenkowska, C. \& Rakowski, A. (2007). The effect of whole-body cryostimulation on the prooxidantantioxidant balance in blood of elite kayakers after training. European Journal of Applied Physiology, Vol. 101, pp. 533-537

42. Yanagisawa O, Nitsu M, Takahashi H ,Goto K,Itai Y, (2003) Evaluations of cooling exercised muscle with MR imaging and spectroscopy .MedSci Sports Exerc;35 : 1517-1523

43. Yamauchi T (1989) Whole-body cryotherapy is a method of extreme cold -175 ${ }^{\circ} \mathrm{C}$ treatment initially used for rheumatoid arthrisis. Z Phys Med Baln Med Klin 15: 311.

44. Zagrobelny Z. \& Zimmer, K. (1999). The use of cryogenic temperatures in medicine and sport physiotherapy. Medycyna Sportowa Vol.94,No. 5,pp. 8 13

45. Zagrobelny Z (2003) Local and whole-body cryotherapy. Urban \& Partner.

46. Zalewski, P, Tafil-Klawe, M, Klawe J, Buszko, K,Lewandowski, A. \& Panowicz, I. (2009). Influence of the whole-body cryotherapy on the hemodynamic parameters in healthy subjects. Acta Bio - Optica et Informatica Medica, Vol.15, No. 3, pp.209-214 